\title{
PEMBENTUKAN MODEL PERLINDUNGAN ANAK BURUH MIGRAN DI KABUPATEN BANYUMAS*
}

\author{
Riris Ardhanariswari, Waluyo Handoko, dan Sofa Marwah \\ Fakultas Hukum dan Fakultas IImu Sosial dan IImu Politik \\ Universitas J enderal Soedirman Purwokerto \\ E-mail: ardhana_1991@yahoo.co.id
}

\begin{abstract}
This paper discusses about the model of protection children of migrant workers that most appropriate and can be used as a reference for the model of child protection that more comprehensive. The approach used in this study is a qualitative action research approach. The selected research location include two villages that representing the rural and semi-urban areas of two districts which they are the basis of migrant workers, such as Kedondong Village District of Sokaraja (semi-urban) and Dawuhan Kulon Village District of Kedungbanteng (rural). Data were selected by using purposive sampling method. Base on research, Model of child protection of migrant workers can be done by more empowering form of social workers in the district by establishing a new institution, the Board for Child Protection of Migrant Workers (BCPMW) at subdistrict and district levels. Membership BCPMW at district level consisting of components Dinsosnakertrans, prospective migrant workers migrant workers, recruitment agency, social worker and observer problems of migrant workers. In carrying out its functions and duties, BCPMW have partnered with Dinsosnakertrans and BapermasPPKB.
\end{abstract}

Keywords: children of migrant workers, child protection model of migrant workers

\begin{abstract}
Abstrak
Tulisan ini membahas mengenai model perlindungan anak buruh migran yang paling tepat dan dapat dijadikan sebagai acuan bagi model perlindungan anak secara lebih menyeluruh. Pendekatan yang digunakan dalam penelitian ini adalah pendekatan kualitatif action research. Lokasi penelitian dipilih dua desa yang mewakili daerah rural dan semi-urban dari dua kecamatan yang menjadi basis buruh migran, yaitu Desa Kedondong Kecamatan Sokaraja (semi-urban) dan Desa Dawuhan Kulon Kecamatan Kedungbanteng (rural). Data dipilih dengan menggunakan purposive sampling. Berdasarkan hasil penelitian, model perlindungan anak buruh dapat dilakukan dengan memberdayakan pekerja sosial yang ada di Kecamatan dengan membentuk Lembaga Perlindungan Anak Buruh Migran (LPABM)) di tingkat Kecamatan dan Kabupaten; Keanggotaan LPABM di tingkat Kabupaten ini harus terdiri dari komponen Dinsosnakertrans, Calon Buruh Migran/TKI, PJ TKI, Pekerja Sosial dan Pemerhati masalah BMI. Dalam menjalankan fungsi dan tugasnya LPABM ini harus bermitra dengan Dinsosnakertrans dan BapermasPPKB.
\end{abstract}

Kata Kunci: buruh migran, anak buruh migran, perlindungan anak buruh migran.

\section{Pendahuluan}

Hasil studi tahap pertama penelitian ini menunjukkan, bahwa permasalahan yang dialami anak buruh migran sampai saat ini belum mendapatkan perhatian dari pemerintah setempat dan organisasi pemerhati anak secara khusus. Padahal UU No. 23 Tahun 2002 ten-

\footnotetext{
Tulisan ini merupakan artikel dari hasil penelitian hibah bersaing dengan Surat Perjanjian Pelaksanaan J asa Tahun Anggaran 2011 No. 1835/ H23. 9/ PN/2011 tanggal 7 April 2011
}

tang Perlindungan Anak (selanjutnya disebut UU Perlindungan anak) telah mengamanatkan untuk terpenuhinya hak-hak dasar anak. Oleh karena itu, diperlukan sebuah sistem yang memungkinkan adanya kerjasama berbagai pihak yang terkait seperti orang tua pengasuh, keluarga, masyarakat dan pemerintah. Hasil studi tahap pertama juga menunjukkan, bahwa fenomena di wilayah rural dan semi-urban dari dua kecamatan yang merupakan basis buruh 
migran, yaitu Kecamatan Sokaraja (Desa Kedondong/ semi-urban) dan Kecamatan Kedungbanteng (Desa Dawuhan Kulon/rural), menunjukkan kondisi yang sama berkaitan dengan permasalahan yang dihadapi anak buruh migran baik di daerah semi-urban maupun rural. ${ }^{1}$

Keberadaan UU No. 23 Tahun 2002 tentang Perlindungan Anak memerlukan bentukbentuk pengejawantahan dalam tataran yang lebih praktis untuk melindungi anak dari berbagai hal yang merugikan sedini mungkin. PerIu dipahami, bahwa UU No. 23 Tahun 2002 merupakan penyempurnaan dari UU Perlindungan Anak sebelumnya (UU No. 39 tahun 1999) yang secara tegas menyebutkan bahwa perlindungan anak selain merupakan tanggung jawab pemerintah, orang tua dan masyarakat, juga menjadi tanggung jawab wali dan lembaga sosial. ${ }^{2}$ Beberapa hasil studi yang merekomendasikan pentingnya pengejewantahan tersebut misalnya mengenai pentingnya penyusunan Perda Perlindungan Anak di tingkat daerah atau perlunya pembentukan kelompok kerja perlindungan anak di tingkat propinsi/ kabupaten. ${ }^{3}$ Berkaitan dengan pentingnya bentuk pengejawantahan UU Perlindungan Anak, hasil studi tahap pertama penelitian ini, sebagaimana diuraikan di atas, menjadi dasar bagi pembentukan model perlindungan anak buruh migran di Kabupaten Banyumas, yang dapat dikembangkan menjadi bentuk perlindungan bagi anak secara menyeluruh. Model perlindungan anak buruh migran yang terbentuk diharapkan dapat diterapkan, sehingga dapat memberikan perlindungan anak dan mampu mendukung pertumbuhan kualitas anak sebagai generasi penerus bangsa.

\footnotetext{
Waluyo Handoko dkk, 2010. Pembentukan Model Perlindungan Anak Buruh Migran di Kabupaten Banyumas (Tahap Pertama), Hibah Bersaing DP2M Dikti.

2 Murniati Ruslan, "Perlindungan Hukum Terhadap Anak", J urnal Bilancia, Vol. 2 No. 1 Tahun 2008, PDIILIPI, Jakarta, hlm. 123-124.

3 Sulikah Asmorowati, "Efektivitas Kebijakan Perlindungan Pekerja Anak dengan Fokus Anak J alanan di Surabaya", J urnal Penelitian Dinamika Sosial, Vol. 7 . No.1/April-2008, FISIP Unair Surabaya; Suradi, "Perlindungan Anak di Nusa Tenggara Barat", Jurnal Penelitian dan Pengembangan Kesejahteraan Sosial, Vol 11 No. 3 Tahun 2006, Kemensos RI Jakarta, hlm. 16.
}

\section{Perumusan Masalah}

Berdasarkan penjelasan di atas penulis tertarik untuk membahas mengenai perumusan model perlindungan anak buruh migran yang paling tepat untuk membantu terpenuhinya hak-hak dasar anak buruh migran di Kabupaten Banyumas, yang dapat dikembangkan menjadi acuan bagi model perlindungan anak secara lebih menyeluruh.

\section{Metode Penelitian}

Penelitian ini merupakan studi aksi yang menggunakan pendekatan kualitatif action research yang diadopsi secara keseluruhan dari strategi action research oleh Irfan Islamy. ${ }^{4}$ Subjek utama penelitian yaitu anak buruh migran dan keluarga yang ditinggalkan, yang dipilih secara purposive dan melibatkan subjek terkait seperti; tokoh masyarakat, kepala desa dan perangkatnya, dinas atau badan pemerintah daerah terkait, dan sebagainya. Lokasi penelitian dipilih dua desa yang mewakili daerah rural dan semi-urban dari dua kecamatan basis buruh migran, yaitu Desa Kedondong Kecamatan Sokaraja (semi-urban) dan Desa Dawuhan Kulon Kecamatan Kedungbanteng (rural). Penentuan informan didukung dengan teknik snowball. Pengumpulan data dilakukan dengan teknik wawancara mendalam (in-depth interview), observasi, dan studi dokumentasi. Data diolah dan dianalisis secara sistematis.

\section{Pembahasan}

\section{Kondisi Umum Sosial Ekonomi Masyarakat Kabupaten Banyumas}

Kabupaten Banyumas memiliki luas wilayah 130,759 ha dan terdiri dari 27 kecamatan yang terbagi menjadi 30 kelurahan dan 201 desa. J umlah penduduk tahun 2010, berdasarkan data BPS Kabupaten Banyumas, mencapai 1.553.902 jiwa dengan laju pertumbuhan penduduk $0,7 \%$ J umlah tersebut terdiri dari lakilaki 777.568 jiwa dan perempuan 776.334 jiwa, dengan tingkat kepadatan penduduk se-

\footnotetext{
Irfan Islamy dalam Masykuri Bakry (ed.), 2003, Metodologi Penelitian Kualitatif: Tinjauan Teoretis dan Praksis, Malang: Lemlit Unisma dan Visipress, hlm. 86-90.
} 
besar $1.192 \mathrm{jiwa} / \mathrm{km}^{2}$. Pertumbuhan ekonomi jika dilihat dari laju PDRB berdasarkan dengan harga konstan 2000 adalah 5,49\% pada tahun 2009 yang naik 0,97\% dari laju PDRB 5,38\% pada tahun 2008. Pentahapan keluarga pra sejahtera/sejahtera, dapat dilihat pada tabel berikut.

Tabel 1. Keluarga Prasejahtera dan Sejahtera di Kabupaten Banyumas 2009

\begin{tabular}{|c|c|c|c|c|}
\hline \multirow[b]{2}{*}{ Tingkatan } & \multicolumn{2}{|c|}{ Alasan } & \multirow[b]{2}{*}{ J umlah } & \multirow{2}{*}{$\begin{array}{l}\text { Per- } \\
\text { sen } \\
(\%)\end{array}$} \\
\hline & $\begin{array}{l}\text { Eko- } \\
\text { nomi }\end{array}$ & $\begin{array}{l}\text { Non } \\
\text { eko- } \\
\text { nomi }\end{array}$ & & \\
\hline $\begin{array}{c}\text { Keluarga } \\
\text { pra } \\
\text { sejahtera }\end{array}$ & 78.800 & 37.450 & 116.250 & 25.28 \\
\hline $\begin{array}{c}\text { Keluarga } \\
\text { sejahtera I }\end{array}$ & 42.486 & 45.331 & 87.817 & 19.10 \\
\hline $\begin{array}{c}\text { Keluarga } \\
\text { sejahtera II }\end{array}$ & - & - & 129.678 & 28.10 \\
\hline $\begin{array}{c}\text { Keluarga } \\
\text { sej ahtera } \\
\text { III }\end{array}$ & - & - & 94.859 & 20.63 \\
\hline $\begin{array}{c}\text { Keluarga } \\
\text { sejahtera } \\
\text { III + }\end{array}$ & - & - & 31.279 & 6,80 \\
\hline
\end{tabular}

Luas wilayah Kec. Kedungbanteng adalah 6,022 ha, yang mempunyai 14 desa dan tidak memiliki kelurahan. Berdasarkan data BPS Kabupaten Banyumas tahun 2010, jumlah penduduk Kecamatan Kedungbanteng pada tahun 2009 yaitu 51.064 jiwa, dengan jumlah penduduk laki-laki sebanyak 26.068 jiwa dan perempuan 24.996 jiwa. Kepadatan penduduk kecamatan jika dilihat dari per desanya yaitu 3.647, sedangkan apabila dilihat dari $\mathrm{km}^{2}$ yaitu 848. Laju pertumbuhan penduduk pada tahun 2009 sebesar 0,83 atau selisih $0,13 \%$ di atas laju pertumbuhan penduduk pada tahun yang sama untuk tingkat Kabupaten Banyumas yaitu 0,7\% Pentahapan keluarga pra sejahtera/ sejahtera, dapat dilihat pada tabel 2 berikut.

Desa Dawuhan Kulon terletak 2 kilometer dari ibukota Kecamatan Kedungbanteng. Jumlah penduduk Dawuhan Kulon, secara struktural ekonomi, terbagi dalam 848 kepala keluarga, dengan ketentuan; jumlah keluarga prasejahtera 478 keluarga, kelurga sejahtera-I
Tabel 2. Keluarga Prasejahtera dan Sejahtera di Kec. Kedungbanteng 2009

\begin{tabular}{|c|c|c|c|c|c|}
\hline \multirow[b]{2}{*}{ Tingkatan } & \multicolumn{2}{|c|}{ Alasan } & \multirow[b]{2}{*}{$\begin{array}{l}\text { J um- } \\
\text { lah }\end{array}$} & \multirow[b]{2}{*}{$\begin{array}{l}\text { Per- } \\
\text { sen } \\
(\%)\end{array}$} & \multirow{2}{*}{$\begin{array}{c}\text { Ting- } \\
\text { kat } \\
\text { kab. } \\
(\%)\end{array}$} \\
\hline & $\begin{array}{l}\text { Eko- } \\
\text { nomi }\end{array}$ & $\begin{array}{l}\text { Non } \\
\text { eko- } \\
\text { nomi }\end{array}$ & & & \\
\hline $\begin{array}{c}\text { Keluarga } \\
\text { pra } \\
\text { sejahtera }\end{array}$ & 2.192 & 1.050 & 2.242 & 16.07 & 25,28 \\
\hline $\begin{array}{c}\text { Keluarga } \\
\text { sejahtera I }\end{array}$ & 1.303 & 1.240 & 2.543 & 28,23 & 19,10 \\
\hline $\begin{array}{c}\text { Keluarga } \\
\text { sejahtera } \\
\text { II }\end{array}$ & - & - & 3.144 & 22.54 & 28.20 \\
\hline $\begin{array}{c}\text { Keluarga } \\
\text { sejahtera } \\
\text { III }\end{array}$ & - & - & 4.292 & 30.77 & 20.63 \\
\hline $\begin{array}{c}\text { Keluarga } \\
\text { sejahtera } \\
\text { III + }\end{array}$ & - & - & 2.728 & 12,39 & 6,80 \\
\hline
\end{tabular}

berjumlah 190 keluarga, keluarga sejahtera II sebanyak 97 keluarga, keluarga sejahtera III 62 keluarga dan keluarga sejahtera III plus berjumlah 21 keluarga (Daftar Isian Perkembangan Desa Dawuhan Kulon tahun 2010)

Penduduk Kecamatan Kedungbanteng, dibanding dengan jumlah penduduk Kecamatan Sokaraja lebih banyak. Pada tahun 2009, berdasarkan data BPS Kabupaten Banyumas tahun 2010, jumlah penduduk Sokaraja ada 76.867 jiwa, dengan jumlah penduduk lakilaki 38.357 jiwa dan perempuan 38.510 jiwa. Tingkat kepadatan penduduk Kecamatan Sokaraja juga lebih padat, apabila dilihat dari per desanya yaitu 4.120 dan jika dilihat dari $\mathrm{km}^{2}$ yaitu 2.478. Sementara itu, laju pertumbuhan penduduk pada tahun 2009 sebesar 0,87 atau selisih $0,17 \%$ di atas laju pertumbuhan penduduk Kabupaten Banyumas yaitu 0,7\% dan relatif berimbang dengan laju pertumbuhan penduduk Kecamatan Kedungbanteng yaitu 0,83. J umlah keluarga sejahtera di Sokaraja prosentasenya jauh di atas Kedungbanteng, demikian pula jika dibandingkan dengan jumlah keluarga sejahtera di tingkat kabupaten, jumlah keluarga sejahtera di Kecamatan Sokaraja prosentasenya juga di atas tingkat kabupaten. Hal tersebut dapat dilihat pada tabel berikut ini. 
Tabel 3. Keluarga Prasejahtera dan Sejahtera di Kec. Sokaraja 2009

\begin{tabular}{|c|c|c|c|c|c|}
\hline \multirow[b]{2}{*}{$\begin{array}{c}\text { Tingkat- } \\
\text { an }\end{array}$} & \multicolumn{2}{|c|}{ Alasan } & \multirow[b]{2}{*}{$\begin{array}{l}\text { J um- } \\
\text { lah }\end{array}$} & \multirow[b]{2}{*}{$\begin{array}{l}\text { Per- } \\
\text { sen } \\
(\%)\end{array}$} & \multirow{2}{*}{$\begin{array}{c}\text { Ting- } \\
\text { kat } \\
\text { kab. } \\
(\%)\end{array}$} \\
\hline & $\begin{array}{l}\text { Eko- } \\
\text { nomi }\end{array}$ & $\begin{array}{l}\text { Non } \\
\text { eko- } \\
\text { nomi }\end{array}$ & & & \\
\hline $\begin{array}{c}\text { Keluarga } \\
\text { pra } \\
\text { sejahtera }\end{array}$ & 1.842 & 597 & 2.212 & 17.15 & 25.28 \\
\hline $\begin{array}{c}\text { Keluarga } \\
\text { sejahtera } \\
\text { I }\end{array}$ & 1.146 & 1.473 & 3.290 & 24.74 & 19.10 \\
\hline $\begin{array}{c}\text { Keluarga } \\
\text { sejahtera } \\
\text { II }\end{array}$ & - & - & 2.796 & 32,89 & 28.10 \\
\hline $\begin{array}{c}\text { Keluarga } \\
\text { sejahtera } \\
\text { III }\end{array}$ & - & - & 3.786 & 29.36 & 20.63 \\
\hline $\begin{array}{c}\text { Keluarga } \\
\text { sejahtera } \\
\text { III + }\end{array}$ & - & - & 912 & 97,07 & 6,80 \\
\hline
\end{tabular}

Desa Kedondong terletak 2 kilometer dari ibukota Kecamatan Sokaraja. J umlah penduduk di Desa Kedondong pada tahun 2009 sejumlah 813 KK dengan jumlah penduduk 3.077 jiwa yang terdiri dari 1.521 penduduk laki-laki dan 1.556 penduduk perempuan. Berdasarkan data peta kemiskinan dari BKM Desa Kedondong, saat ini tercatat 1.464 penduduk termasuk kategori penduduk miskin, sedangkan jumlah KK yang miskin adalah 366 keluarga. Untuk kategori penduduk miskin yang memerlukan kegiatan produktif sebanyak 1.098 jiwa (Daftar Monografi Dinamis Desa Kedondong tahun 2009).

Pemetaan Permasalahan Anak Buruh Migran dalam Perspektif UU Perlindungan Anak dan Posisi Pemerintah Kabupaten Banyumas

Hak asasi anak merupakan bagian dari hak asasi manusia yang termuat dalam UUD 1945 dan Konvensi PBB tentang Hak-hak Anak. Anak sebagai bagian dari warga negara memiliki hak yang wajib dijamin, dihormati, dilindungi, dan dipenuhi oleh negara. Dari sisi kehidupan berbangsa dan bernegara, anak adalah masa depan bangsa serta generasi penerus cita-cita bangsa, sehingga setiap anak berhak atas kelangsungan hidup, tumbuh, dan berkembang, berpartisipasi serta berhak atas per- lindungan dari tindak kekerasan dan diskriminasi, serta hak sipil dan kebebasan. Berikut dijabarkan hak-hak anak sesuai UU Perlindungan Anak dan kondisi anak buruh migran di Kabupaten Banyumas. ${ }^{5}$

Tabel 4. Hak-Hak Anak Menurut UU Perlindungan Anak dan Kondisi yang Dialami Anak Buruh Migran di Kabupaten Banyumas

\begin{tabular}{|c|c|c|}
\hline No & $\begin{array}{l}\text { Hak anak menurut } \\
\text { UU Perlindungan Anak }\end{array}$ & $\begin{array}{l}\text { Kondisi di } \\
\text { lapangan }\end{array}$ \\
\hline 1 & $\begin{array}{l}\text { Setiap anak berhak un- } \\
\text { tuk dapat hidup, tum- } \\
\text { buh, berkembang, dan } \\
\text { berpartisipasi secara wa- } \\
\text { jar sesuai dengan harkat } \\
\text { dan martabat kemanusia- } \\
\text { an, serta mendapat per- } \\
\text { lindungan dari kekerasan } \\
\text { dan diskriminasi. (Pasal } \\
\text { 4) }\end{array}$ & $\begin{array}{l}\text { Dalam kasus ke- } \\
\text { beradaan bapak } \\
\text { dan atau ibu di } \\
\text { perantauan, seti- } \\
\text { daknya belum } \\
\text { memenuhi hak a- } \\
\text { nak untuk ber- } \\
\text { partisipasi, yaitu } \\
\text { keinginannya } \\
\text { yang "tidak dide- } \\
\text { ngar" karena di- } \\
\text { tinggal bapak } \\
\text { dan atau ibu ke } \\
\text { luar negeri, apa- } \\
\text { lagi banyak dari } \\
\text { buruh migran itu } \\
\text { yang berangkat } \\
\text { ketika anak mas- } \\
\text { ih bayi dan kese- } \\
\text { harian anak-anak } \\
\text { itu sering mena- } \\
\text { nyakan kebera- } \\
\text { daan bapak atau } \\
\text { ibunya. }\end{array}$ \\
\hline 2 & $\begin{array}{l}\text { Setiap anak berhak atas } \\
\text { suatu nama sebagai } \\
\text { identitas diri dan status } \\
\text { kewarganegaraan. (Pasal } \\
\text { 5) }\end{array}$ & $\begin{array}{l}\text { Kondisi yang ada } \\
\text { biasanya anak } \\
\text { saat lahir mengi- } \\
\text { kuti kewargane- } \\
\text { garaan orang tua } \\
\text { dan sudah diberi } \\
\text { nama sebagai i- } \\
\text { dentitas. }\end{array}$ \\
\hline 3 & $\begin{array}{l}\text { Setiap anak berhak untuk } \\
\text { beribadah menurut aga- } \\
\text { manya, berpikir, dan ber- } \\
\text { ekspresi sesuai dengan } \\
\text { tingkat kecerdasan dan } \\
\text { usianya, dalam bimbi- } \\
\text { ngan orang tua. (Pasal 6) }\end{array}$ & $\begin{array}{l}\text { a. Dalam kegiat- } \\
\text { an beribadah } \\
\text { anak kurang } \\
\text { mendapatkan } \\
\text { bimbingan dari } \\
\text { orang tuanya, } \\
\text { apalagi ketika } \\
\text { ditinggal orang } \\
\text { tuanya menja- } \\
\text { di buruh mig- } \\
\text { ran, \& orang } \\
\text { tua berangga- } \\
\text { pan ketika ke- } \\
\text { butuhan eko- } \\
\text { nomi anak su- }\end{array}$ \\
\hline
\end{tabular}

5 Waluyo Handoko dkk, op.cit, hlm. 49 


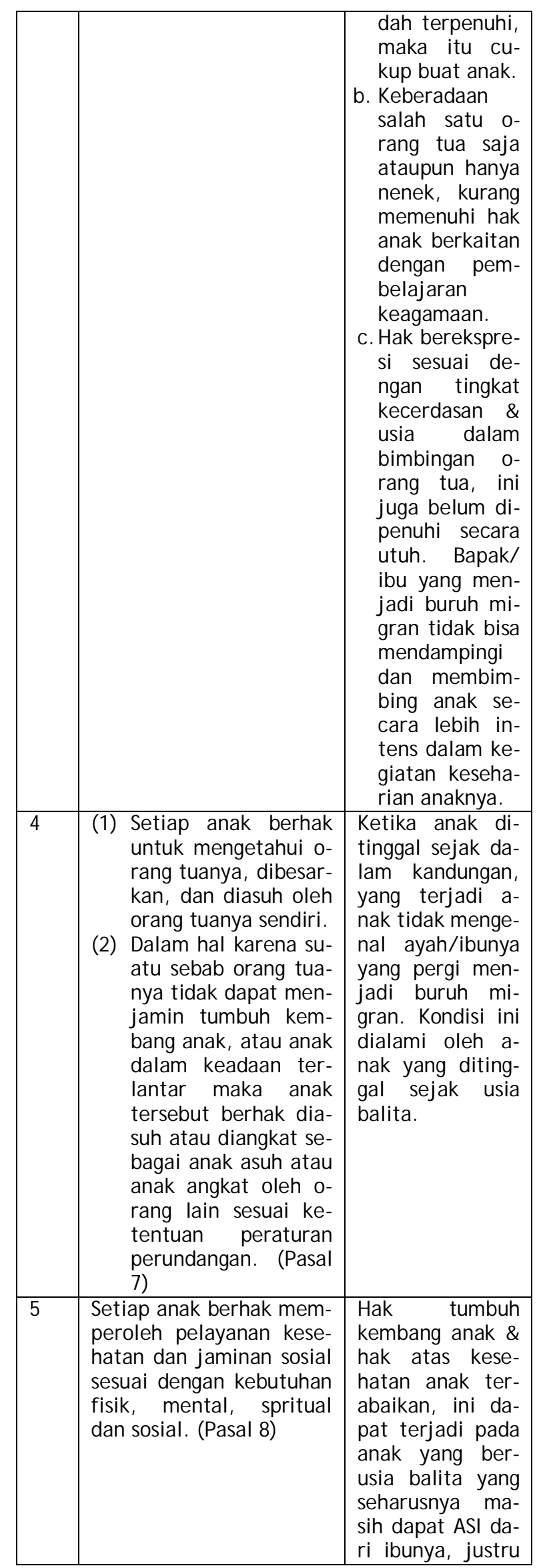

\begin{tabular}{|c|c|c|}
\hline & & $\begin{array}{lr}\text { ditinggal } & \text { ibunya } \\
\text { menjadi } & \text { buruh } \\
\text { migran. } & \\
\end{array}$ \\
\hline 6 & $\begin{array}{l}\text { (1) Setiap anak berhak } \\
\text { memperoleh pendi- } \\
\text { dikan dan pengaja- } \\
\text { ran dalam rangka pe- } \\
\text { ngembangan priba- } \\
\text { dinya dan tingkat ke- } \\
\text { cerdasannya sesuai } \\
\text { dengan minat dan } \\
\text { bakatnya. } \\
\text { (2) Selain hak anak se- } \\
\text { bagaimana dimaksud } \\
\text { dalam ayat (1), khu- } \\
\text { sus bagi anak yang } \\
\text { menyandang cacat } \\
\text { juga berhak mempe- } \\
\text { roleh pendidikan lu- } \\
\text { ar biasa, sedangkan } \\
\text { bagi anak yang me- } \\
\text { miliki keunggulan ju- } \\
\text { ga berhak mendapat- } \\
\text { kan pendidikan khu- } \\
\text { sus. (Pasal 9) }\end{array}$ & $\begin{array}{l}\text { Untuk hak pendi- } \\
\text { dikan ketika a- } \\
\text { nak ditinggal o- } \\
\text { rang tuanya, hak } \\
\text { pendidikan ku- } \\
\text { rang terpenuhi. } \\
\text { Mereka memang } \\
\text { masih disekolah- } \\
\text { kan, berarti su- } \\
\text { dah memenuhi } \\
\text { hak anak untuk } \\
\text { memperoleh } \\
\text { pendidikan. Na- } \\
\text { mun tanggung } \\
\text { jawab hanya di- } \\
\text { serahkan pada } \\
\text { nenek, bude a- } \\
\text { tau bibinya, se- } \\
\text { hingga pengawa- } \\
\text { san secara terus } \\
\text { menerus relatif } \\
\text { kurang. }\end{array}$ \\
\hline 7 & $\begin{array}{l}\text { Setiap anak berhak me- } \\
\text { nyatakan dan didengar } \\
\text { pendapatnya, menerima, } \\
\text { mencari, dan memberi- } \\
\text { kan informasi sesuai de- } \\
\text { ngan tingkat kecerdasan } \\
\text { dan usianya demi pe- } \\
\text { ngembangan dirinya se- } \\
\text { suai dengan nilai kesu- } \\
\text { silaan dan kepatutan. } \\
\text { (Pasal 10) }\end{array}$ & $\begin{array}{l}\text { Hak ini belum } \\
\text { terpenuhi, terli- } \\
\text { hat dari ketidak- } \\
\text { mampuan anak } \\
\text { untuk mencegah } \\
\text { orang tuanya be- } \\
\text { rangkat ke luar } \\
\text { negeri untuk be- } \\
\text { kerja, dan anak- } \\
\text { anak juga cende- } \\
\text { rung tidak tahu } \\
\text { informasi ten- } \\
\text { tang orang tua- } \\
\text { nya di luar nege- } \\
\text { ri. }\end{array}$ \\
\hline 8 & $\begin{array}{l}\text { Setiap anak berhak untuk } \\
\text { beristirahat dan meman- } \\
\text { faatkan waktu luang, } \\
\text { bermain, berekreasi, dan } \\
\text { berkreasi sesuai dengan } \\
\text { minat, bakat, dan tingkat } \\
\text { kecerdasannya demi pe- } \\
\text { ngembangan diri. (Pasal } \\
\text { 11) }\end{array}$ & $\begin{array}{l}\text { Hak ini sudah di- } \\
\text { penuhi, karena } \\
\text { anak diberi ke- } \\
\text { bebasan untuk } \\
\text { bermain, bergaul } \\
\text { dengan anak se- } \\
\text { baya, bahkan ka- } \\
\text { dang terlalu di- } \\
\text { beri kebebasan } \\
\text { untuk bermain. }\end{array}$ \\
\hline 9 & $\begin{array}{l}\text { Setiap anak penyandang } \\
\text { cacat berhak mempero- } \\
\text { leh rehabilitasi, bantuan } \\
\text { sosial, dan pemeliharaan } \\
\text { taraf kesejahteraan sosi- } \\
\text { al. (Pasal 12) }\end{array}$ & $\begin{array}{l}\text { Kondisi yang ada } \\
\text { belum ditemu- } \\
\text { kan anak buruh } \\
\text { migran yang ca- } \\
\text { cat. }\end{array}$ \\
\hline 10 & $\begin{array}{l}\text { (1) Setiap anak selama } \\
\text { dalam pengasuhan o- } \\
\text { rang tua, wali, atau } \\
\text { pihak lain manapun } \\
\text { yang bertanggung ja- } \\
\text { wab atas pengasuh- } \\
\text { an, berhak mendapat }\end{array}$ & $\begin{array}{l}\text { ketika pengasuh- } \\
\text { an hanya dari } \\
\text { salah satu bapak } \\
\text { atau ibu, bahkan } \\
\text { seringkali tidak } \\
\text { keduanya, hanya } \\
\text { ada nenek atau }\end{array}$ \\
\hline
\end{tabular}




\begin{tabular}{|c|c|c|}
\hline & $\begin{array}{l}\text { perlindungan dari: } \\
\text { a diskriminasi; } \\
\text { b eksploitasi, baik } \\
\text { ekonomi maupun } \\
\text { seksual; } \\
\text { c penelantaran; } \\
\text { d kekejaman, } \\
\text { kekerasan, dan } \\
\text { penganiayaan; } \\
\text { e ketidakadilan; } \\
\text { f perlakuan salah } \\
\text { lainnya. } \\
\text { Dalam hal orang tua, } \\
\text { wali atau pengasuh } \\
\text { anak melakukan se- } \\
\text { gala bentuk perlaku- } \\
\text { an sebagaimana di- } \\
\text { maksud dalam ayat } \\
\text { (ayat 1), maka pela- } \\
\text { ku dikenakan pem- } \\
\text { beratan hukum. } \\
\text { (Pasal 13) }\end{array}$ & $\begin{array}{l}\text { bibi atau bude, } \\
\text { perlindungan a- } \\
\text { nak tidak utuh. } \\
\text { Kekerasan dan } \\
\text { diskriminasi bisa } \\
\text { saja dialami oleh } \\
\text { anak yang bera- } \\
\text { da dalam penga- } \\
\text { suhan salah satu } \\
\text { bapak atau ibu } \\
\text { atau nenek atau } \\
\text { bibi atau bude- } \\
\text { nya. Ketika bibi } \\
\text { atau bude punya } \\
\text { anak dan seka- } \\
\text { ligus mengasuh } \\
\text { anak yang diting- } \\
\text { gal pergi orang } \\
\text { tua, bisa mem- } \\
\text { berikan perlaku- } \\
\text { an yang berbeda } \\
\text { meskipun dilaku- } \\
\text { kan tidak secara } \\
\text { sadar. }\end{array}$ \\
\hline 11 & $\begin{array}{l}\text { Setiap anak berhak untuk } \\
\text { diasuh oleh orang tuanya } \\
\text { sendiri, kecuali jika ada } \\
\text { alasan dan/ aturan hukum } \\
\text { yang sah menunjukkan } \\
\text { bahwa pemisahan itu a- } \\
\text { dalah demi kepentingan } \\
\text { terbaik bagi anak dan } \\
\text { merupakan pertimbangan } \\
\text { terakhir. (Pasal 14) }\end{array}$ & $\begin{array}{l}\text { Dalam kasus ke- } \\
\text { beradaan bapak } \\
\text { dan atau ibu di } \\
\text { perantauan, be- } \\
\text { lum memenuhi } \\
\text { hak anak untuk } \\
\text { berpartisipasi, } \\
\text { yaitu keinginan- } \\
\text { nya yang "tidak } \\
\text { didengar" karena } \\
\text { ditinggal bapak } \\
\& \text { atau ibu yang } \\
\text { berangkat keluar } \\
\text { negeri, apalagi } \\
\text { banyak dari bu- } \\
\text { ruh migran itu } \\
\text { yang berangkat } \\
\text { ketika anaknya } \\
\text { masih bayi dan } \\
\text { keseharian anak- } \\
\text { anak itu sering } \\
\text { menanyakan ke- } \\
\text { beradaan bapak } \\
\text { atau ibunya. }\end{array}$ \\
\hline
\end{tabular}

Tabel 4 di atas menunjukkan hak-hak dasar anak buruh migran yang belum terpenuhi adalah hak berpartisipasi, hak beribadah sesuai agama, berpikir dan berekspresi, hak untuk di asuh dan dibesarkan orang tua, hak untuk memperoleh pelayanan kesehatan dan jaminan sosial, hak untuk didengar dan menyatakan pendapatnya, serta hak untuk diasuh oleh orang tuanya sendiri. Hak-hak dasar anak buruh migran yang kurang terpenuhi adalah hak untuk diasuh orang lain jika orang tua tidak dapat menjamin, hak perlindungan dan pengasuhan, dan hak memperoleh pendidikan dan pengajaran. Sementara hak anak untuk beristirahat dan memanfaatkan waktu luang, serta hak untuk identitas dan kewarganegaraan masih dapat dipenuhi. Hasil pengkajian terhadap hak-hak dasar anak tersebut menegaskan, bahwa keberadaan orang tua merupakan faktor primer terhadap anak yang masih dalam umur pertumbuhan. ${ }^{6} \mathrm{Hal}$ ini berarti, apabila orang tua bekerja di luar, pengaruh yang diderita oleh anak tentu besar sekali terhadap terpenuhi tidaknya hak-hak dasar anak buruh migran.

Pemerintah pusat maupun daerah, sejauh ini lebih banyak menangani kekerasan terhadap buruh migran sendiri. Perhatian berbagai kalangan pun terkuras untuk menyelesaikan persoalan tenaga kerja di luar negeri. Hal ini berarti, secara implementatif solusi yang diberikan juga lebih diarahkan pada orang tua yang menjadi buruh migran, bukan anak mereka yang ditinggalkan di kampung halaman. ${ }^{7}$ Namun demikian, Pemerintah Kabupaten Banyumas setidaknya sudah memiliki instrumen hukum untuk memastikan pemenuhan hak anak dan penegakan hukum. Komitmen Pemerintah Kabupaten Banyumas untuk menjamin hak-hak anak dilakukan melalui Dinsosnakertrans, khususnya Bidang Pembinaan dan Pengembangan Potensi Sosial (BPPPS), serta BapermasPPKB yang bermitra dengan Pusat Pelayanan Terpadu dan Perlindungan Korban Kekerasan Berbasis Gender dan Anak (PPTPPK-KBGA).

6 Lianny Sholihin, "Tindakan Kekerasan Terhadap Anak dalam Keluarga", Jurnal Pendidikan Penabur, No.3 Tahun III Desember 2004, hlm. 138-139 tersedia di http: www.bpkpenabur.or.id diakses pada tanggal 14 J anuari 2012.

7 Misalnya kajian Antari Nuryandani dan E. Kristi Poerwandari, VoL. 13 No. 03 Agustus 2007, "Strategi Coping pada Perempuan Buruh Migran Indonesia yang Mengalami kekerasan di Timur Tengah", J urnal JPS, Fakultas Psikologi UI, hal, 257; Sukanda Husain, Vol II No. 1 Tahun 2009, "Perlindungan Hak-Hak Tenaga Kerja Indonesia", J urnal Konstitusi FH Universitas Riau, hal. 7. 
Tabel 5. Rekapitulasi Data Dinsonakertrans Kabupaten Banyumas Bidang BPPPS dalam Penanganan PMKS Tahun 2008-2010

\begin{tabular}{|c|c|c|c|c|c|}
\hline \multirow[t]{2}{*}{ No } & \multirow{2}{*}{$\begin{array}{l}\text { Jenis } \\
\text { PMKS }\end{array}$} & \multicolumn{3}{|c|}{ Tahun } & \multirow{2}{*}{$\begin{array}{c}\text { Kete- } \\
\text { rangan }\end{array}$} \\
\hline & & 2008 & 2009 & 2010 & \\
\hline 1 & $\begin{array}{l}\text { Anak bali- } \\
\text { ta terlan- } \\
\text { tar }\end{array}$ & 987 & 844 & 566 & $\begin{array}{l}\text { J umlah } \\
\text { tersebut } \\
\text { terpilah }\end{array}$ \\
\hline 2 & $\begin{array}{l}\text { Anak ter- } \\
\text { lantar }\end{array}$ & 2450 & 1702 & 1512 & $\begin{array}{l}\text { antara } \\
\text { yang su- }\end{array}$ \\
\hline 3 & $\begin{array}{l}\text { Anak kor- } \\
\text { ban tin- } \\
\text { dak keke- } \\
\text { rasan }\end{array}$ & 52 & 20 & 5 & $\begin{array}{l}\text { dah dita- } \\
\text { ngani } \\
\text { dan } \\
\text { belum di- }\end{array}$ \\
\hline 4 & $\begin{array}{l}\text { Anak na- } \\
\text { kal }\end{array}$ & 292 & 315 & 273 & tangani \\
\hline 5 & $\begin{array}{l}\text { Anak ja- } \\
\text { lanan }\end{array}$ & 144 & 369 & 278 & \\
\hline 6 & $\begin{array}{l}\text { Anak ca- } \\
\text { cat }\end{array}$ & 4104 & 2646 & 2407 & \\
\hline 7 & $\begin{array}{l}\text { Wanita } \\
\text { rawan } \\
\text { sosial } \\
\text { ekonomi }\end{array}$ & 5839 & 7533 & 5803 & \\
\hline 8 & $\begin{array}{l}\text { Wanita } \\
\text { korban } \\
\text { tindak } \\
\text { kekeras- } \\
\text { an }\end{array}$ & 81 & 38 & 21 & \\
\hline 9 & $\begin{array}{l}\text { Lanjut } \\
\text { usia ter- } \\
\text { lantar }\end{array}$ & 4415 & 4100 & 4674 & \\
\hline 10 & $\begin{array}{l}\text { Lanjut u- } \\
\text { sia korban } \\
\text { tindak ke- } \\
\text { kerasan }\end{array}$ & 1 & 0 & 3 & \\
\hline 11 & $\begin{array}{l}\text { Penyan- } \\
\text { dang } \\
\text { cacat }\end{array}$ & 6025 & 4464 & 6410 & \\
\hline 12 & $\begin{array}{l}\text { Penyan- } \\
\text { dang ca- } \\
\text { cat bekas }\end{array}$ & 1298 & 1332 & 382 & \\
\hline 13 & $\begin{array}{l}\text { Penyan- } \\
\text { dang } \\
\text { HIV/AIDS }\end{array}$ & 6 & 10 & 9 & \\
\hline 14 & $\begin{array}{l}\text { Tuna susi- } \\
\text { la }\end{array}$ & 282 & 256 & 382 & \\
\hline 15 & Pengemis & 198 & 322 & 163 & \\
\hline 16 & $\begin{array}{l}\text { Gelan- } \\
\text { dangan }\end{array}$ & 244 & 72 & 163 & \\
\hline 17 & $\begin{array}{l}\text { Bekas na- } \\
\text { rapidana } \\
\text { (bekas na- } \\
\text { pi) }\end{array}$ & 1092 & 964 & 548 & \\
\hline 18 & $\begin{array}{l}\text { Pekerja } \\
\text { migran } \\
\text { bermasa- } \\
\text { lah }\end{array}$ & 100 & 45 & 0 & \\
\hline 19 & $\begin{array}{l}\text { Korban } \\
\text { NAPSA }\end{array}$ & 247 & 153 & 84 & \\
\hline 20 & Keluarga & 106.4 & 115.5 & 97.09 & \\
\hline
\end{tabular}

\begin{tabular}{|c|c|c|c|c|}
\hline & $\begin{array}{l}\text { fakir mis- } \\
\text { kin }\end{array}$ & 45 & 97 & 1 \\
\hline 21 & $\begin{array}{l}\text { Keluarga } \\
\text { berumah } \\
\text { tak layak } \\
\text { huni }\end{array}$ & 17348 & 23077 & $\begin{array}{c}23.49 \\
0\end{array}$ \\
\hline 22 & $\begin{array}{l}\text { Keluarga } \\
\text { bermasa- } \\
\text { lah sosial } \\
\text { psikologis }\end{array}$ & 276 & 212 & 175 \\
\hline 23 & $\begin{array}{l}\text { Keluarga } \\
\text { rentan }\end{array}$ & 2577 & 522 & 612 \\
\hline 24 & $\begin{array}{l}\text { Komunitas } \\
\text { adat ter- } \\
\text { pencil }\end{array}$ & 0 & 0 & 0 \\
\hline 25 & $\begin{array}{l}\text { Korban } \\
\text { bencana } \\
\text { alam }\end{array}$ & 1296 & 747 & 788 \\
\hline 26 & $\begin{array}{l}\text { Korban } \\
\text { bencana } \\
\text { sosial }\end{array}$ & 292 & 49 & 8 \\
\hline
\end{tabular}

Sumber: Dinsosnakertrans Kabupaten Banyu-mas, 20082011

Tabel 5 di atas menunjukkan upaya yang dilakukan oleh BPPPS Dinsosnakertrans untuk menangani masalah Penanganan Penyandang Masalah Kesejahteraan Sosial (PMKS) dari tahun 2008-2011. Fokus BPPPS lebih pada masalah kesejahteraan anak, yaitu melalui Seksi Pemberdayaan Keluarga, Lansia dan Kesejahteraan Anak. Masalah PMKS yang ditangani meliputi anak balita terlantar, anak terlantar, anak korban tindak kekerasan, anak nakal, anak jalanan dan anak cacat. Cukup signifikannya jumlah PMKS yang terkait dengan anak di kabupaten ini tentunya patut menjadi perhatian bersama untuk dicarikan solusinya. Berdasarkan studi Sudarso tentang Penyandang Masalah Kesejahteraan Sosial di Kota Surabaya menegaskan, bahwa anak penyandang masalah kesejahteraan sosial sesungguhnya merupakan korban yang patut ditolong, didukung dan difasilitasi agar dapat menolong dirinya sendiri untuk lebih berdaya. ${ }^{8}$

Sejauh ini BPPPS Dinsosnakertrans masih lebih fokus pada masalah kesejahteraan anak dan belum menyentuh sampai persoalan tidak terpenuhinya hak-hak anak buruh migran. Salah satu contoh adalah masalah anak

Sudarso, "Penyandang Masalah Kesejahteraan Sosial di Kota Surabaya", Jurnal Masyarakat Kebudayaan dan Politik, Vol. XIX, No.1, Januari 2006, FISIP Unair Surabaya, hlm. 5 
buruh migran yang terlantar di Desa Dawuhan Kulon, menjadi anak nakal, dan tidak naik kelas. Sekdes Dawuhan Kulon menyatakan bahwa anak tersebut belum mendapatkan perhatian instansi terkait, karena peran pekerja sosial yang masih kurang aktif (Wawancara tgl 5 J uli 2011). Seperti halnya juga informasi dari Amin Sachuri, Kades Kedondong, bahwa pekerja sosial tingkat Kecamatan Sokaraja meskipun aktif bekerja namun belum menyentuh permasalahan anak buruh migran di desanya (Wawancara tgl 7 Juli 2011). Pekerja sosial adalah kepanjangan tangan BPPPS Dinsosnakertrans di tingkat kecamatan. Namun kendalanya adalah sulitnya menguatkan jejaring sosial yang sudah terbentuk, karena hanya bersifat sukarelawan. Saat ini jumlah pekerja sosial BPPPS hanya 11 orang, yang berarti tidak di setiap kecamatan BPPPS mempunyai pekerja sosial.

Tabel 6. Rekapitulasi Data PPT-PPK-KBGA dalam Penanganan Kasus Kekerasan Berbasis Gender dan Anak Periode J anuari 2008-Mei 2011

\begin{tabular}{|c|l|c|c|c|c|}
\hline No & \multicolumn{1}{|c|}{$\begin{array}{l}\text { Bentuk } \\
\text { kekerasan }\end{array}$} & \multicolumn{4}{|c|}{ Tahun } \\
\cline { 3 - 6 } & KDRT & 64 & 56 & 38 & 19 \\
\hline 2 & $\begin{array}{l}\text { Kekerasan } \\
\text { terhadap anak } \\
\text { (pencabulan } \\
\text { dan } \\
\text { penganiayaan) }\end{array}$ & 36 & 74 & 57 & 13 \\
\hline 3 & $\begin{array}{l}\text { Perdagangan } \\
\text { manusia dan } \\
\text { buruh migran }\end{array}$ & 13 & 11 & 5 & 4 \\
\hline 4 & $\begin{array}{l}\text { Kekerasan } \\
\text { dalam } \\
\text { pacaran }\end{array}$ & 7 & 7 & 14 & 4 \\
\hline 5 & Perkosaan & 1 & 2 & 4 & - \\
\hline 6 & ABH & - & 15 & 16 & 7 \\
\hline 7 & $\begin{array}{l}\text { Pelecehan } \\
\text { seksual }\end{array}$ & - & 4 & - & - \\
\hline 8 & Ganti kelamin & - & - & 1 & - \\
\hline 9 & Hak asuh anak & - & - & 1 & 1 \\
\hline 10 & $\begin{array}{l}\text { Penemuan } \\
\text { anak }\end{array}$ & - & - & - & 1 \\
\hline & J umlah & $\mathbf{1 2 1}$ & $\mathbf{6 8}$ & $\mathbf{1 3 6}$ & $\mathbf{4 9}$ \\
\hline
\end{tabular}

Sumber: PPT-PPK-KBGA dan BapermasPPKB Kabupaten Banyumas, 2008-2011

Sementara itu BapermasPPKB melakukan kegiatannya dalam menangani masalah anak dengan bermitra dengan PPT-PPK-KBGA yang beranggotakan unsur-unsur instansi pene- gak hukum, instansi pemerintah, LSM, organisasi sosial, PUG, PPGA. Tabel 6 di atas menunjukkan upaya PPT-PPK-KBGA dalam menangani kekerasan berbasis gender dan anak dari tahun 2008-2011. Khusus penanganan masalah anak, misalnya berkaitan dengan kekerasan terhadap anak, baik pencabulan atau penganiayaan, $\mathrm{ABH}$, hak asuh anak, penemuan anak, dan kasus lainnya yang tidak secara spesifik menyebut anak sebagai korban, namun memungkinkan anak juga menjadi korban di dalamnya, seperti kasus perkosaan atau pelecehan seksual. Kekerasan yang berupa pencabulan atau penganiayaan terhadap anak termasuk kasus yang dominan di Kabupaten Banyumas dari tahun ke tahun. Selain itu masalah perdagangan anak juga perlu diwaspadai peningkatannya di Kabupaten Banyumas. Hal ini mengingat keberadaan kabupaten ini sebagai salah satu basis buruh migran di J awa Tengah. Kajian Seto Mulyadi menunjukkan, bahwa peningkatan jumlah buruh migran menjadi salah satu faktor yang mempengaruhi tingginya angka perdagangan anak. ${ }^{9}$

PPT-PPK-KBGA dalam melakukan kegiatannya lebih fokus pada persoalan anak yang menjadi korban kekerasan, atau anak yang melakukan pelanggaran hukum. Namun, mereka hanya bekerja berdasarkan pengaduan saja. Tindakan yang bersifat jemput bola belum dilakukan, termasuk terhadap permasalahan anak buruh migran. Perlantarnya anak buruh migran, padahal memiliki potensi untuk berkembang menjadi kasus kekerasan terhadap anak atau anak tersebut melakukan pelanggaran hukum.

Upaya pembenahan dan perbaikan kondisi perlindungan anak oleh pemerintah didasari oleh strategi terpadu antara penyusunan peraturan perundang-undangan sebagai landasan hukum, perbaikan sistem pelayanan dan pengawasan, serta penyusunan berbagai pedoman untuk memastikan adanya perlindungan anak dalam semua kebijakan, program, kegiatan dan anggaran serta kerangka penilaiannya.

9 Seto Mulyadi, Vol. 12 No.1 Tahun 2007, "Perdagangan Anak di Indonesia", J urnal IImiah Untar, Universitas Tarumanegara, J akarta, hlm. 12 
Peta permasalahan belum terpenuhinya hak dasar anak-anak buruh migran sesuai amanat UU Perlindungan Anak, serta posisi Dinsosnakertrans (BPPPS) dan BapermasPPKB (PPT-PPKKBGA) dalam penanganan masalah anak, dipotret dalam skema Gambar 1. Garis-garis terputus pada Gambar 1 menunjukkan belum adanya perhatian terhadap kondisi tidak terpenuhinya hak-hak dasar anak buruh migran yang diatur UU Perlindungan Anak oleh Dinsosnakertrans (BPPPS) dengan BapermasPPKB, serta belum menyentuhnya program dan kegiatan kedua lembaga tersebut terhadap permasalahan anak buruh migran. Kedua instansi yang dihubungkan dengan garis terputus menunjukkan kerjasama antara kedua lembaga tersebut belum dalam bentuk kerjasama penuh, masih bersifat insidental dan belum memiliki dasar peraturan yang jelas.

Fenomena permasalahan anak merupakan permasalahan yang dapat terjadi baik di daerah rural ataupun semi-urban. Kondisi terlantarnya anak buruh migran dapat menimpa siapa saja. Baik di tingkat rural atau semi urban, mereka dapat menjadi anak yang terlantar, yang dapat saja berkembang menjadi tindak pelanggaran hukum oleh anak atau anak menjadi korban kekerasan karena pengawasan dan perlindungan yang sangat kurang. Perlu diingat, bahwa segala resiko yang dapat mempengaruhi anak menjadi tanggung jawab penuh baik pemerintah maupun masyarakat, yang didukung oleh penegakan hukum sebagai bentuk control and empaty terhadap masalah yang dihadapi anak. ${ }^{10}$ Oleh karena itu, dibutuhkan strategi tertentu untuk mempercepat upaya pemenuhan hak anak buruh migran melalui pembentukan model perlindungan anak buruh migran di Kabupaten Banyumas. Model yang terbentuk dapat dikembangkan menjadi model perlindungan anak secara menyeluruh.

\section{Langkah-langkah Pembentukan Model Perlin- dungan Anak Buruh Migran}

10 Ika Saimima, "Perlindungan Anak Terhadap Anak yang Berkonflik dengan Hukum", Jurnal Kajian IImiah Ubhara Jaya, Vol 9 No 3 Tahun 2008, Lemlit Ubhara, hlm. 938.
Perlindungan anak buruh migran harus berdasarkan pada rinsip-prinsip yang terkait dengan prinsip-prinsip dalam perlindungan anak pada umumnya. Prinsip yang harus dilakukan dalam perlindungan anak buruh migran meliputi: Pertama, prinsip atas hak kelangsungan hidup dan tumbuh kembang, bahwa setiap anak memiliki hak yang melekat atas kehidupan dan negara wajib menjamin kelangsungan hidup serta perkembangan anak sampai batas maksimal; kedua, prinsip non diskriminasi, bahwa semua hak yang diakui dalam UU Perlindungan Anak harus diberlakukan kepada setiap anak tanpa pembedaan apapun, berdasarkan asal-usul, suku, ras, agama, politik dan sosial ekonomi; ketiga, prinsip kepentingan terbaik untuk anak, bahwa dalam setiap tindakan yang menyangkut anak yang dilakukan oleh pemerintah, masyarakat, badan legislatif dan badan yudikatif, maka kepentingan yang terbaik bagi anak harus menjadi pertimbangan utama; dan keempat, Prinsip penghargaan terhadap pendapat anak, bahwa anak yang memiliki pandangan-pandangan sendiri dan mempunyai hak untuk menyatakan pandanganpandangannya secara bebas dalam semua hal yang mempengaruhi anak.

Pemerintah daerah dalam memberikan perlindungan anak secara umum dan khususnya untuk anak buruh migran harus berpedoman pada Peraturan Menteri Negara Pemberdayaan Perempuan Nomor 3 Tahun 2008 tentang Pedoman Pelaksanaan Perlindungan Anak. Pedoman pelaksanaan perlindungan anak adalah segala kegiatan untuk menjamin dan melindungi anak dan hak-hak anak yang meliputi: pertama, bertahan hidup, yaitu standar hidup yang layak, makanan bergizi, sandang, papan, pelayanan kesehatan, penghidupan yang layak, perlindungan dari segala bentuk kekerasan; kedua, tumbuh kembang, yaitu memungkinkan anak tumbuh dan berkembang secara optimal sesuai dengan potensi, melalui pendidikan, bermain dan memanfaatkan waktu luang, aktifitas sosial budaya, dan akses terhadap informasi; ketiga, mendapatkan perlindu- 


\section{Gambar 1. Skema Permasalahan Anak Buruh Migran Dalam Perspektif UU No.23 Tahun 2002 dan Posisi Pemerintah Kabupaten Banyumas Terhadap Masalah Anak}

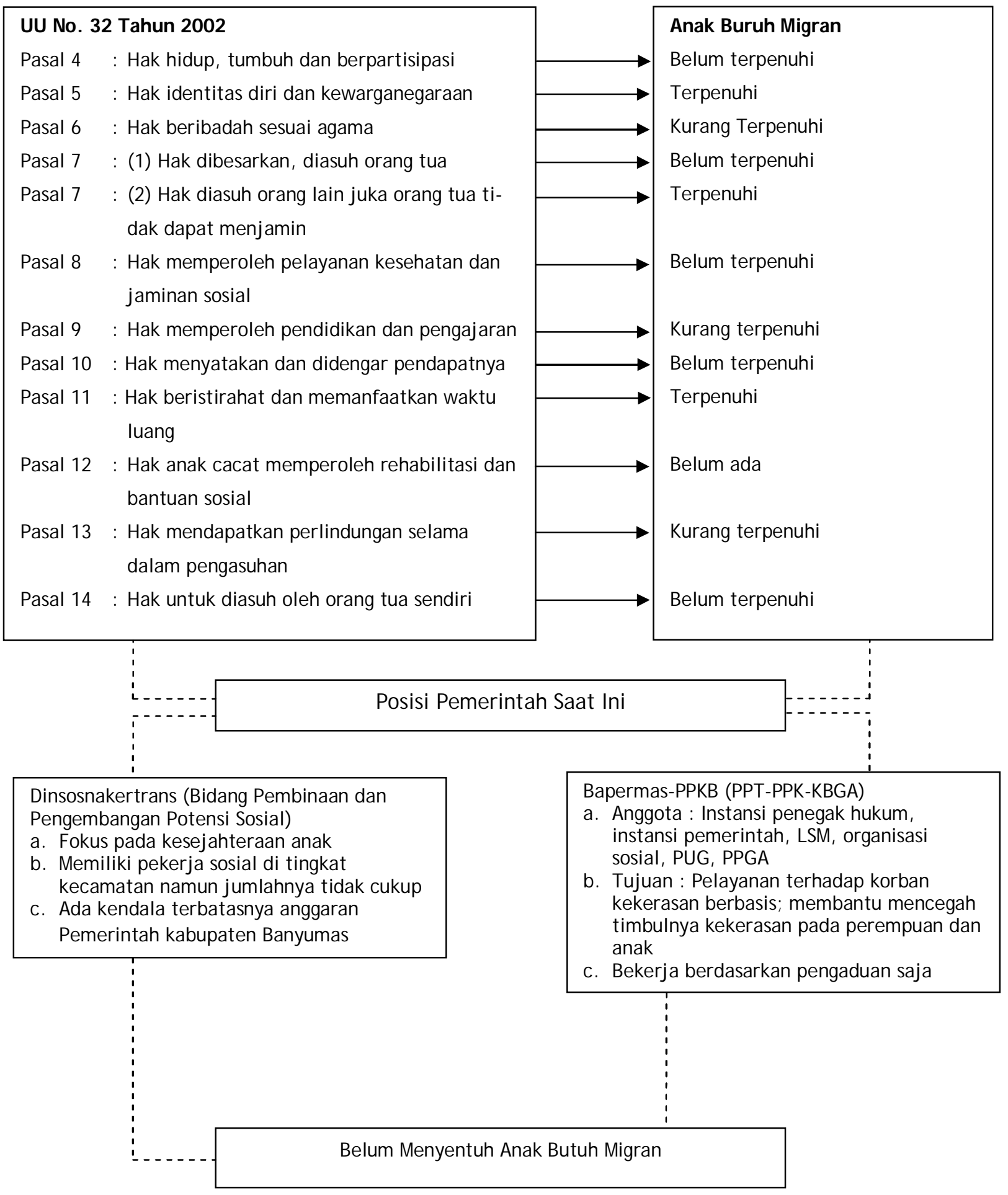


ngan, meliputi perlindungan dari kekerasan, eksploitasi dan diskriminasi, termasuk trafiking; dan keempat, berpartisipasi, yaitu agar anak didengar pendapatnya dan dapat berperan aktif dalam komunitasnya, sesuai dengan potensi yang dimiliki terutama dalam berbagai hal yang menyangkut kepentingan anak.

Keputusan Menteri Pemberdayaan Perempuan Nomor 3 Tahun 2008 mengatur ruang lingkup pedoman pelaksanaan perlindungan anak ini meliputi perencanaan, pelaksanaan, pemantauan dan evaluasi, pelaporan, pendanaan dan pembinaan pengawasan. Dalam pelaksanaan pembangunan perlindungan anak ini adalah Pengarusutamaan Hak Anak (PUHA). Dalam tataran pemerintah daerah, bupati berkewajiban mengintegrasikan kebijakan, program, dan kegiatan perlindungan anak ke dalam perencanaan pembangunan daerah. Oleh karena itu, harus ada komitmen dari bupati terkait masalah perlindungan anak. Tahapan-tahapan yang perlu dilakukan dalam pembentukan model perlindungan anak buruh migran adalah sebagai berikut. Pertama, pemahaman terhadap kondisi yang dialami yang dialami anak buruh migran di lapangan sesuai dengan amanat UU Perlindungan Anak. Hal ini dapat dilihat pada Tabel 4 dan Gambar 1 di atas. Kedua, diperlukan adanya pemahaman para pihak yang terlibat (terutama ayah, ibu, dan keluarga) dalam perlindungan anak buruh migran terkait dengan hak-hak anak yang diatur daIam UU Perlindungan Anak.

Ketiga, pemahaman tentang perlindungan anak juga harus diberikan pada masyarakat termasuk juga aparat pemerintah desa. Pemerintah kecamatan dan desa idealnya punya peran yang strategis berkaitan dengan permasalahan buruh migran dan anak buruh migran. Namun pemerintah kecamatan dan desa sendiri belum memiliki data buruh migran yang baik dan ketika ada persoalan yang menyangkut buruh migran, mereka mengalami kesulitan untuk membantu warga.

Keempat, Pekerja sosial harus paham terlebih dahulu terkait dengan perlindungan anak secara umum sebagaimana diatur dalam UU Perlindungan Anak, kemudian pekerja so- sial juga harus berperan aktif turun ke desa untuk memantau persoalan-persoalan yang berkaitan dengan perlindungan anak secara umum dan perlindungan anak buruh migran secara khusus. Optimalisasi peran pekerja sosial sampai ke tingkat desa dengan demikian sangat dibutuhkan.

Kelima, Pemerintah Kabupaten Banyumas telah menunjukkan komitmennya untuk menangani permasalahan anak melalui Dinsosnakertrans khususnya BPPPS, serta BapermasPPKB yang bermitra dengan PPT-PK-KBGA. Namun, BPPPS Dinsosnakertrans dan PPT-PKKBGA masih kurang dalam melakukan koordinasi dan kerjasama dalam melaksanakan kegiatan penanganan anak. Koordinasi keduanya diperlukan, karena fokus kegiatannya bersinggungan.

Keenam, Pembentukan Lembaga Perlindungan Anak Buruh Migran (LPABM). Lembaga ini dibentuk di tingkat kecamatan dan kabupaten, yang keanggotaannya terdiri dari komponen Dinsosnakertrans, calon buruh migran/ TKI, PJ TKI, pekerja sosial dan pemerhati masalah buruh migran (kalau di Banyumas ada organisasi SERUNI).

Berdasarkan pentahapan penyusunan model di atas, maka persoalan mendasar berkaitan dengan perlindungan anak buruh migran adalah pemahaman mengenai hak-hak dan kewajiban anak secara umum dan khususnya anak buruh migran sesuai dengan UU Perlindungan Anak. Hal ini dapat dilakukan dengan memberikan sosialisasi UU Perlindungan Anak. Sosialisasi ini dapat dilakukan oleh berbagai pihak mulai dari instansi pemerintah maupun juga dari kalangan akademisi.

\section{Model Perlindungan Anak Buruh Migran}

Perlindungan anak buruh migran di Kabupaten Banyumas ini tidak hanya menjadi tanggung jawab orang tua, tapi juga menjadi tanggung jawab keluarga (nenek, kakek, bude, bulik dan sebagainya), masyarakat, pekerja sosial dan juga pemerintah kabupaten dan juga lembaga legislatif. Pemerintah Kabupaten dalam hal ini tentunya dinas/kantor/badan yang tugas pokok dan fungsinya berkaitan dengan persoalan anak. Dalam hal ini adalah Din- 
sosnakertrans dan BapermasPPKB. Gambar 2 adalah model yang disusun peneliti berkaitan dengan perlindungan anak buruh migran di Kab Banyumas. Model perlindungan anak buruh migran ini tentunya melibatkan berbagai pihak baik dari unsur pemerintah kabupaten, calon buruh migran/TKI, PJ TKI, pekerja sosial, dan pemerhati buruh migran/TKI.

Perlindungan anak buruh migran pada dasarnya menjadi tanggung jawab pemerintah kabupaten. Pelaksanaan perlindungan anak buruh migran ini adalah lebih memberdayakan pekerja sosial yang ada di kecamatan dengan memberikan lembaga baru dan kewenangan yang baru juga yaitu dengan membentuk Lembaga Perlindungan Anak Buruh Migran (LPABM) di tingkat kecamatan dan kabupaten. Lembaga ini mempunyai tugas dan fungsi sebagai berikut: pertama, pendataan calon buruh migran/ TKI dan anak buruh migran/TKI; kedua, menerima kontribusi dari calon buruh

Gambar 2. Model Perlindungan Anak Buruh Migran

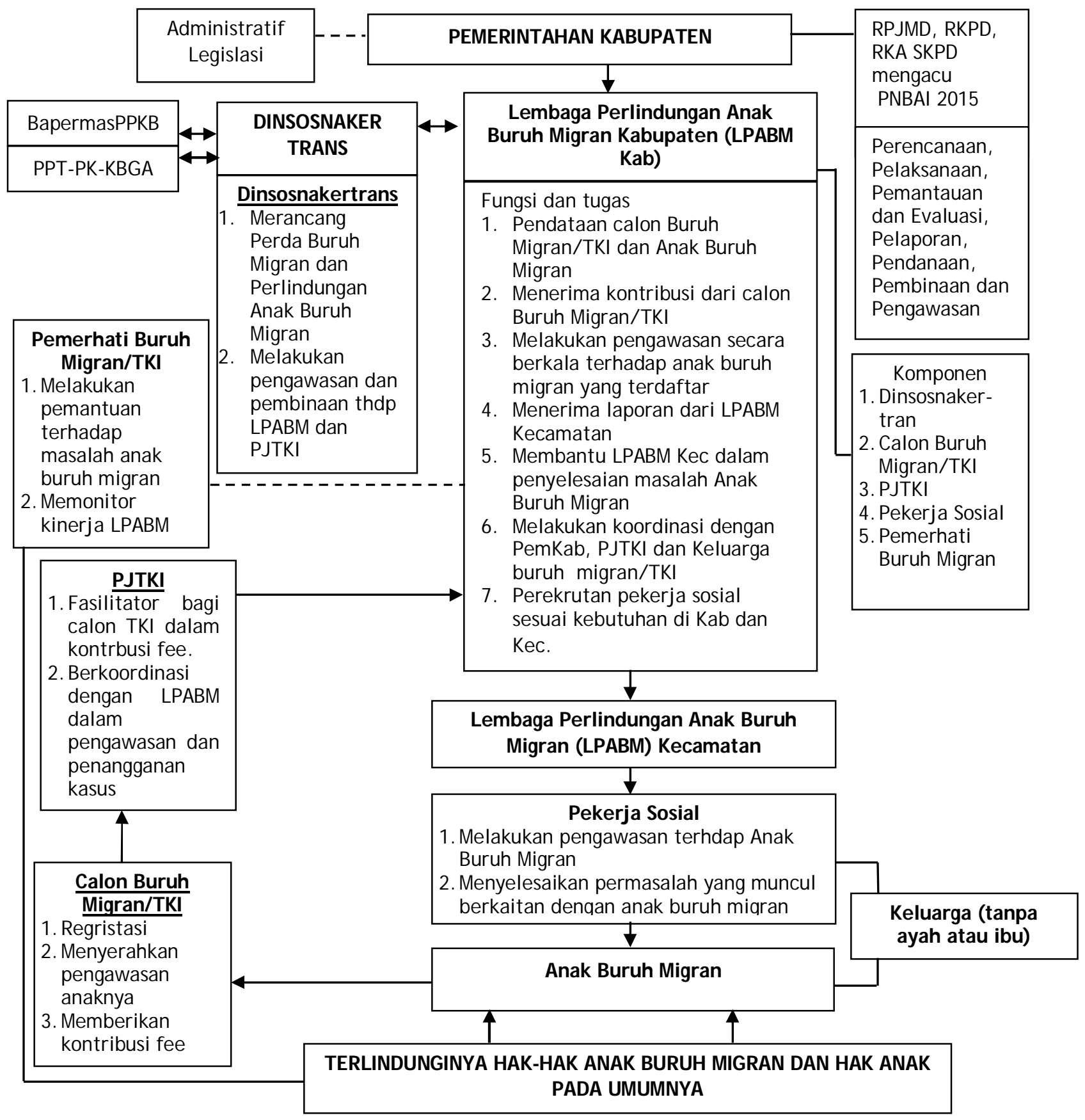


migran/TKI; ketiga, melakukan pengawasan secara berkala terhadap anak buruh migran yang terdaftar; keempat, menerima laporan dari LPABM Kecamatan; kelima, membantu LPABM Kecamatan dalam penyelesaian masalah anak buruh migran; keenam, melakukan koordinasi dengan pemerintah kabupaten, PJ TKI dan keluarga buruh migran/TKI; dan ketujuh, perekrutan jumlah pekerja sosial menyesuaikan dengan kebutuhan di kabupaten dan kecamatan. Keanggotaan LPABM terdiri dari komponen Dinsosnakertrans, calon buruh migran/TKI, PJ TKI, pekerja sosial dan pemerhati masalah buruh migran.

Komitmen Pemerintahan Kabupaten Banyumas dalam memberikan perlindungan anak buruh migran dapat dilakukan melalui tindakan legislasi dan administratif. Tindakan legislasi berupa pengeluaran produk hukum, pengalokasikan anggaran, melakukan kontrol dalam memberikan perlindungan anak buruh migran secara khusus dan perlindungan anak secara umum. Tindakan administratif berupa pelaksanaan kebijakan, pengusulan angggaran, penyusunan program, penguatan dan pelibatan partisipasi masyarakat dalam rangka perlindungan buruh migran secara khusus dan perlindungan anak secara umum.

Tindakan administrasi dan legislasi ini harus tercermin dalam RPJ MD, RKPD dan RKA SKPD yang mengacu pada Program Nasional Bagi Anak Indonesia (PNBAl) 2015, yang pada akhirnya akan mewujudkan terlindunginya hak-hak anak buruh migran secara khusus dan hak anak secara umum. Dalam pelaksanaannya harus sesuai dengan Pedoman Pelaksanaan Perlindungan Anak yang ruang lingkupnya meliputi Perencanaan, Pelaksanaan, Pemantauan dan Evaluasi, Pelaporan, Pendanaan, Pembinaan dan Pegawasan.

LPABM di tingkat Kabupaten ini bermitra dengan Dinsosnakertrans dan BapermasPPKB, karena LPABM dalam melaksanakan fungsi dan tugasnya akan berkaitan dengan Dinsosnakertrans dan BapermasPPKB. Dinsosnakertrans diharapkan dapat merancang dan mengusulkan Raperda tentang Buruh Migran dan Perlindung- an Anak Buruh Migran. Dinsosnakertrans juga yang mempunyai tugas melakukan pengawasan dan pembinaan terhadap LPABM dan PJTKI. BapermasPPKB bermitra dengan PPT-PK-KBGA, artinya dalam penanganan perlindungan anak buruh migran LPABM juga harus bermitra dengan PPT-PK-KBGA.

LPABM ini berjenjang di tingkat kabupaten dan kecamatan. Ujung tombak dari pelaksanaan perlindungan anak buruh migran ini adalah pekerja sosial, karena merekalah yang harus bekerja untuk melakukan pengawasan terhadap anak buruh migran dan menyelesaikan ketika ada permasalahan. Pekerja sosial juga harus proaktif melakukan pengawasan terhadap anak buruh migran. Ketika pekerja sosial menemukan ada anak buruh migran yang belum terlindungi maka pekerja sosial dapat langsung berkoordinasi dengan PPT-PK-KBGA untuk langsung menangani persoalan yang ada. Jika bersoalan itu tidak dapat tertangani baru berkoordinasi dengan LPABM di tingkat kecamatan dan jika tidak tertangani lagi maka dilaporkan pada LPABM kabupaten.

Kesejahteraan pekerja sosial dapat ditingkatkan dengan cara memperbesar anggaran untuk pekerja sosial dari APBD melalui anggaran Dinsosnakertrans, sebagai wujud komitmen dari Pemeruntah Kabupaten Banyumas untuk memberikan perlindungan terhadap anak buruh migran. Selain itu ada kontribusi fee yang harus diberikan oleh calon buruh migran/ TKI yang akan berangkat ke luar negeri. Kontribusi fee ini merupakan wujud keterikatan antara calon buruh migran dengan LPABM yang dalam prakteknya dilakukan oleh pekerja sosial yang melakukan perlindungan terhadap anak buruh migran ketika para buruh migran sudah ke luar negeri.

Keterlibatan PJTKI sangat diperlukan LPABM ini, karena PJ TKI ini merupakan wakil/ agen yang paling mudah dihubungi ketika ada persoalan yang menyangkut buruh migran ataupun juga anak buruh migran. PJTKI ini juga merupakan fasilitator bagi calon buruh migran berkaitan dengan kontribusi fee yang harus diberikan oleh calon buruh migran untuk 
LPABM. Pada saat calon buruh migran belum dapat membayar kontribusi fee, maka yang harus membayar terlebih dahulu adalah PJ TKI. PJTKI ini harus berkoordinasi dengan LPABM dalam rangka melakukan pengawasan dan penanganan apabila terjadi kasus yang menyangkut anak buruh migran.

Peran dari pemerhati buruh migran juga sangat penting. Di Kabupaten Banyumas sudah ada lembaga yang bernama SERUNI yang bergerak dalam persoalan yang dihadapi buruh migran. Dalam hal perlindungan anak buruh migran, pemerhati buruh migran berperan melakukan pemantauan terhadap masalah anak buruh migran dan memonitor kinerja LPABM baik di tingkat kecamatan maupun kabupaten.

\section{Penutup}

Simpulan

Berdasarkan hasil penelitian dan uraian di atas disimpulkan, bahwa perlindungan anak buruh migran menjadi tanggung jawab semua pihak baik orang tua, keluarga, masyarakat, dan pemerintah setempat. Model perlindungan anak buruh diterapkan dengan lebih memberdayakan pekerja sosial dengan memberikan lembaga dan kewenangan baru, yaitu dengan membentuk LPABM di tingkat kecamatan dan kabupaten. Keanggotaan LPABM di tingkat kabupaten harus terdiri dari komponen Dinsosnakertrans, calon buruh migran/TKI, PJ TKI, pekerja sosial dan pemerhati masalah buruh migran. Dalam menjalankan fungsi dan tugasnya LPABM ini harus bermitra dengan Dinsosnakertrans dan BapermasPPKB.

\section{Saran}

Berdasarkan simpulan di atas, ada beberapa saran yang penulis ajukan. Pertama, segera disusun Rancangan Peraturan Daerah perlindungan Buruh Migran/TKI dan Perlindungan Anak Buruh Migran/TKl; kedua, perlu segera diinisiasi dan dilanjutkan dengan pembentukan LPABM di Kabupaten Banyumas untuk mengatasi persoalan yang berkaitan dengan perlindungan anak buruh migran; ketiga, kerjasama dan koordinasi yang sinergi antara LPABM, Dinsosnakertrans dan BappermasPPKB ini harus ada dan terus ditingkatkan; dan keempat, perlu sosialisasi pada masyarakat tentang perlindungan anak khususnya mengenai hak-hak dan kewajiban dari anak.

\section{Daftar Pustaka}

Asmorowati, Sulikah. "Efektivitas Kebijakan Perlindungan Pekerja Anak dengan Fokus Anak J alanan di Surabaya". J urnal Penelitian Dinamika Sosial, Vol. 7 - No.1. FISIP Unair. April 2008;

Bakry, Masykuri (ed.). 2003. Metodologi Penelitian Kualitatif: Tinjauan Teoretis dan Praksis, Malang: Lemlit Unisma dan Visipress;

Handoko dkk, Waluyo. 2010. Pembentukan Model Perlindungan Anak Buruh Migran di Kab. Banyumas. Hibah Bersaing Tahap I. Purwokerto: DP2M Dikti/ UNSOED;

Husain, Sukanda. "Perlindungan Hak-Hak Tenaga Kerja Indonesia". J urnal Konstitusi Vol II No. 1 2009. FH Universitas Riau;

Mulyadi, Seto. "Perdagangan Anak di Indonesia". Jurnal IImiah Untar, Vol. 12 No.1. Univ. Tarumanegara. hlm. 12. 2007;

Nuryandani, Antari dan E. Kristi Poerwandari. "Strategi Coping pada Perempuan Buruh Migran Indonesia yang Mengalami Kekerasan di Timur Tengah", J urnal J PS, Vol. 13 No. 03 Agustus 2007. Fakultas Psikologi Ul;

Ruslan, Murniati. "Perlindungan Hukum Terhadap Anak". Jurnal Bilancia, Vol. 2 No. 1 2008. J akarta: PDII-LIPI;

Saimima, Ika. "Perlindungan Hukum Terhadap Anak yang Berkonflik dengan Hukum". J urnal Kajian IImiah Ubhara J aya, Vol 9 No 3 2008. Lemlit Ubhara;

Sholihin, Lianny. "Tindakan Kekerasan Terhadap Anak dalam Keluarga", J urnal Pendidikan Penabur, No.3 Tahun III Desember 2004. Lihat di http: www.bpkpenabur.or.id diakses pada tanggal 14 J anuari 2012.

Sudarso. "Penyandang Masalah Kesejahteraan Sosial di Kota Surabaya". Jurnal Masyarakat Kebudayaan dan Politik, Vol. XIX, No. $1 \mathrm{~J}$ anuari 2006. FISIP Unair;

Suradi, "Perlindungan Anak di Nusa Tenggara Barat". Jurnal Penelitian dan Pengembangan Kesejahteraan Sosial, Vol 11 No. 3 2006. Kemensos RI. 